\title{
Chromosomal and plasmid-mediated fluoroquinolone resistance in human Salmonella enterica infection in Ghana
}

Godfred Acheampong ${ }^{1}$, Michael Owusu ${ }^{1,2}$, Alex Owusu-Ofori ${ }^{3,4}$, Isaac Osei ${ }^{1}$, Nimako Sarpong ${ }^{5}$, Augustina Sylverken ${ }^{1,6}$, Hung-Jui Kung ${ }^{7}$, Shu-Ting Cho ${ }^{7}$, Chih-Horng Kuo ${ }^{7}$, Se Eun Park ${ }^{8,9}$, Florian Marks ${ }^{8}$, Yaw Adu-Sarkodie ${ }^{3}$ and Ellis Owusu-Dabo ${ }^{10^{*}}$ (I)

\begin{abstract}
Background: Salmonella infection poses significant public health threat globally, especially in resource-limited countries. Emergence and spread of antibiotic resistant strains to fluoroquinolones have led to treatment failures and increased mortality in Salmonella infection. However, there is dearth of information regarding mechanisms of resistance to fluoroquinolones in Ghana. This study therefore sought to identify chromosomal mutations and plasmid-mediated resistance as possible mechanisms of fluoroquinolone resistance from clinical isolates in Ghana.

Methods: This was a retrospective study of archived isolates biobanked at Kumasi Centre for Collaborative Research in Tropical Medicine, Ghana. Isolates were obtained from blood, stool and oropharynx samples at two hospitals, between May, 2016 and January, 2018. Salmonella identification was done using standard microbiological protocols and antibiotic susceptibility testing performed by Kirby-Bauer disc diffusion method. Isolates with intermediate susceptibility and/or resistance to nalidixic acid and/or ciprofloxacin were selected and examined for chromosomal mutations by Sanger sequencing and plasmid-mediated resistance by PCR.

Results: Of 133 biobanked isolates cultured, 68 (51.1\%) and 16 (12\%) were identified as Salmonella Typhi and nontyphoidal Salmonella (NTS), respectively. Sequence analysis of gyrA gene revealed the presence of 5 different nonsynonymous mutations, with the most frequent mutation (lle203Ser) occurring in 12 out of 13 isolates tested. Gyrase B (gyrB) gene had 1 nonsynonymous mutation in 3 out of 13 isolates, substituting phenylalanine with leucine at codon 601 (Phe601Leu). No mutation was observed in parC and parE genes. Two NTS isolates were found to harbour gnrS plasmid-mediated resistant gene of molecular size $550 \mathrm{bp}$ with high ciprofloxacin MIC of $0.5 \mu \mathrm{g} / \mathrm{ml}$.

Conclusion: This study reports for the first time in Ghana plasmid-mediated fluoroquinolone resistant gene gnrs in Salmonella clinical isolates. Nonsynonymous mutations of gyrA and gyrB genes likely to confer Salmonella reduced susceptibility to ciprofloxacin were also reported.
\end{abstract}

Keywords: Fluoroquinolone resistance, Plasmids, Salmonella enterica, Mutations

\footnotetext{
*Correspondence: owusudabo@yahoo.com; eowusu-dabo.chs@knust.edu.gh

${ }^{10}$ Department of Global and International Health, School of Public Health,

Kwame Nkrumah University of Science and Technology, Kumasi, Ghana

Full list of author information is available at the end of the article
}

(C) The Author(s). 2019 Open Access This article is distributed under the terms of the Creative Commons Attribution 4.0 International License (http://creativecommons.org/licenses/by/4.0/), which permits unrestricted use, distribution, and reproduction in any medium, provided you give appropriate credit to the original author(s) and the source, provide a link to the Creative Commons license, and indicate if changes were made. The Creative Commons Public Domain Dedication waiver (http://creativecommons.org/publicdomain/zero/1.0/) applies to the data made available in this article, unless otherwise stated. 


\section{Background}

Human Salmonella enterica infection poses a significant public-health challenge globally, especially in low-tomiddle income countries in sub-Saharan Africa and South Asia where sanitation is poor [1]. The situation is worsened by an increasing rate of emergence and distribution of antibiotic resistant strains [2-4].

One surveillance study has demonstrated an obvious increase in overall antimicrobial resistance from 20 to $30 \%$ in the early 1990s to as high as 70\% in the early 2000s [5]. This report was based on old generic antibiotics which are not currently in use. Chloramphenicol, ampicillin and sulfamethoxazole trimethoprim used to be the drugs of choice for treating Salmonella infection for over a decade [6] . However, because of increased resistance to these first-line drugs, physicians have resorted to ciprofloxacin (a fluoroquinolone) [7]. Since its introduction, there has not been structured surveillance mechanism(s) to identify mutations possibly associated with its resistance in Ghana. Availability of only few new antibiotics, has placed enormous value on investigations into resistance strains of bacteria. The World Health Organisation (WHO) has listed fluoroquinolone-resistant Salmonella spp. as part of the priority pathogens for which new antibiotics are urgently needed [8]. Although phenotypic resistance could be available in some clinical laboratories, there is paucity of data on molecular investigations of fluoroquinolone resistant genes associated with Salmonella infection in Ghana and many African countries.

Fluoroquinolone resistance is mainly due to two mechanisms: chromosomally mediated mutations occurring at the quinolone resistance determining regions (QRDR) of topoisomerase genes ( $g y r A, \operatorname{gyr} B$, parC and parE genes) and resistance mediated by plasmids [9]. The latter is further divided into 3 different routes that confer decreased susceptibility to fluoroquinolones: 1) quinolone resistance proteins (encoded by qnr genes ( $q n r A, q n r B, q n r C, q n r D, q n r S$ ) that shield DNA gyrase from the effect of fluoroquinolones); 2) aac (6')-Ib-cr resistance mechanism (an aminoglycoside acetyltransferase that modifies fluoroquinolones by acetylating the free nitrogen on the C7 ring of the drug, decreasing binding affinity), and 3) plasmid-mediated resistance by OqxAb and QepA efflux systems [10, 11].

Fluoroquinolones resistance mediated by plasmids have been identified in some developed countries such as United States of America, United Kingdom and France [9, 12, 13]. With the high rate of spread of plasmid-mediated resistance determinants coupled with some factors such as international travels, there is a possibility of fluoroquinolone resistant Salmonella strains circulating in Ghana. More often than not, fluoroquinolone resistance in Salmonella enterica is mediated by gyrA mutations [3, 14], with few reported cases of gyrB mutations [15] and very few cases of topoisomerase IV (parC and parE) genes. Mutation results in a significant reduction of the drug-enzyme binding, and as such the ability for fluoroquinolones to inhibit DNA ligation is totally restricted $[16,17]$. Both chromosomal and plasmid-encoded fluoroquinolone resistance are responsible for conferring low-level resistance to fluoroquinolones [18], nonetheless, high level-resistance (with increasing MIC up to 250-fold) has been documented [19].

Fluoroquinolone resistant Salmonella strains with multiple gyr and par mutations have been reported from Cambodia, India and Nepal [20, 21]. In Africa, fluoroquinolone resistant strains of Salmonella are known to circulate in countries such as Kenya, Tanzania, Malawi, South Africa, Zambia, Democratic Republic of Congo and Nigeria [4, 22, 23]. However, meta analysis conducted by Cuypers et al., revealed lower prevalence and spread of these strains in Africa compared to Asia [8].

This study therefore sought to identify resistance associated with mutations in the topoisomerase genes of Salmonella and plasmid-mediated resistant genes associated with fluoroquinolone resistance in Salmonella strains from Ghana.

\section{Methods \\ Study design and study area}

This was a retrospective study of archived isolates (from blood, stool and oropharynx samples) biobanked at Kumasi Centre for Collaborative Research in Tropical Medicine (KCCR), Ghana, between May, 2016 and January, 2018. These isolates were collected as part of a larger study that sought to investigate the burden of severe typhoid in sub-Saharan Africa with six countries in participation (Ghana, Burkina Faso, Democratic Republic of Congo, Ethiopia, Nigeria and Madagascar). Nonetheless, this report focused only on the Ghanaian site. Study population comprised patients that presented with fever at Komfo Anokye Teaching Hospital (KATH) and Agogo Presbyterian Hospital (APH) in the Kumasi Metropolis and Asante-Akim North district, respectively, both located in the middle belt of Ghana. KATH serve as a tertiary hospital in an urban setting whereas APH is a primary health facility in a rural area of Ghana.

\section{Ethics approval}

The main study protocol was reviewed and approved by the Committee for Human Research Publications and Ethics (CHRPE) at the School of Medical Sciences, Kwame Nkrumah University of Science and Technology (KNUST) (Approval Number: CHRPE/AP/188/18).

\section{Data collection}

Study participants' biodata such as age and gender were collected from the data department of KCCR. Information regarding the source of isolates, total number of 
samples received and processed were retrieved from laboratory data.

\section{Laboratory procedures \\ Bacterial culture}

Biobanked isolates were removed from $-80^{\circ} \mathrm{C}$ freezer (Thermo Scientific), thawed and sub-cultured unto three standard growth media: Blood Agar (BA - Columbia agar base supplemented with 5\% sheep blood), chocolate agar (CA) and macConkey agar (Mac) (BD, Franklin Lakes, New Jersey, USA) under sterile working condition. All the plates were incubated aerobically overnight at $35^{\circ} \mathrm{C}-37^{\circ} \mathrm{C}$ except for CA plates which was incubated in $5 \% \mathrm{CO}_{2}$ for microaerophilic condition.

\section{Bacterial identification}

Salmonella was identified based on colonial morphology on the various agar, microscopic presentation, latex agglutination test, biochemical tests (including API20E), as well as serotyping (by White-Kauffmann Le-Minor scheme) using commercially available serotyping kit from BD (Franklin Lakes, New Jersey, USA). On both the BA and CA, small, creamy gamma (y) hemolytic colonies consistent with Salmonella sp. was recorded. Gram negative short rods with small colourless non-lactose fermenting colonies on Mac was also documented. Biochemical tests such as triple sugar iron (TSI), urease, citrate tests were performed to aid in Salmonella identification from other enterobacteria based on sugars fermentation, urease production and citrate utilisation, respectively. Isolation and identification of other gram negative and positive bacteria were done according to standard microbiological protocols.

\section{Antibiotic susceptibility testing}

We performed antimicrobial susceptibility testing on all biobanked isolates confirmed as Salmonella according to Clinical and Laboratory Standards Institute (CLSI) guidelines [24]. Susceptibility to ampicillin $(10 \mu \mathrm{g})$, amoxiclav (amoxicillin \& clavulanic acid; 20/10 $\mu \mathrm{g}$ ), ceftriaxone $(30 \mu \mathrm{g})$, trimethoprim/sulfamethoxazole (1.25/ $23.75 \mu \mathrm{g})$, ciprofloxacin $(5 \mu \mathrm{g})$, gentamicin $(10 \mu \mathrm{g})$, tetracycline $(30 \mu \mathrm{g})$, chloramphenicol $(30 \mu \mathrm{g})$, ceftazidime $(30 \mu \mathrm{g})$, cefotaxime $(30 \mu \mathrm{g})$ and nalidixic acid $(30 \mu \mathrm{g})$ was tested on Mueller Hinton agar (BD, USA) using the Kirby-Bauer disc diffusion method. The breakpoints of the various antibiotics used were in line with CLSI 2018. Resistance to fluoroquinolones, defined as isolates with intermediate susceptibility and/or resistance to nalidixic acid (surrogate marker for ciprofloxacin resistance) and/ or ciprofloxacin were selected for Minimum Inhibitory Concentration (MIC). Enterobacteria such as E. coli and Klebsiella sp. that were resistant to 3rd generation cephalosporins in this study were further screened to detect the presence of extended spectrum beta-lactamase
(ESBL) enzyme using double-disc diffusion method on Mueller Hinton agar according to CLSI guidelines [24]. Again, S. aureus resistant to cefoxitin were regarded as methicillin-resistant Staphylococcus aureus (MRSA).

\section{MIC determination}

Minimum inhibitory concentration (MIC) was performed on ciprofloxacin/nalidixic acid intermediate and/ or resistant isolates using ciprofloxacin E-test (epsilometer test) according to the manufacturers recommendation (Oxoid, Wesel, Germany) to confirm ciprofloxacin resistance. E-test gives a direct quantification of antimicrobial susceptibility in the form of discrete MIC values. Isolates with ciprofloxacin breakpoint concentration $(\mu \mathrm{g} / \mathrm{ml})$ of $\leq 0.06 \mu \mathrm{g} / \mathrm{ml}$ was documented as sensitive (S); between 0.12 and $0.5 \mu \mathrm{g} / \mathrm{ml}$ as intermediate (I); and $\geq 1 \mu \mathrm{g} / \mathrm{ml}$ was reported as resistant (R) following the CLSI guidelines.

\section{Quality control}

Escherichia coli ATCC 25922 and Salmonella Typhimurium ATCC 14028 were set up together with the test organisms to control media, biochemical tests, potency of antibiotic discs, and ciprofloxacin E-test strip.

\section{Molecular detection of fluoroquinolone resistant genes DNA extraction}

Genomic DNA was extracted from ciprofloxacin and/or nalidixic acid resistant and/or intermediate isolates using spherolyse DNA isolation kit (HainLife Science, Nehren, Germany) according to manufacturer's instructions. Extracted DNA were used as templates for detection of chromosomally-encoded mutations in the topoisomerase genes and plasmid-mediated fluoroquinolone resistant genes.

\section{Amplification of topoisomerase genes}

Detection and amplification of gyrA, gyrB, parC and parE genes by PCR was performed using primers shown in Table 1. Twenty-five microlitres of One Taq Quick-Load 2x Master Mix with standard buffer (New England Biolabs ${ }^{\circ}$ Inc) was added to $1 \mu \mathrm{l}$ each of $10 \mu \mathrm{M}$ forward and reverse primers respectively. Twenty-two microlitres of nucleasefree water was added to the mastermix and finally, $1 \mu \mathrm{l}$ DNA template to obtain a reaction volume of $50 \mu$ l.

Amplification using Veriti thermal cycler was conducted using the following PCR cycling condition: an initial denaturation at $94.0^{\circ} \mathrm{C}$ for $30 \mathrm{~s} ; 30$ cycles of $94.0{ }^{\circ} \mathrm{C}$ for $30 \mathrm{~s},{ }^{*} 60 / 54 / 53 / 52{ }^{\circ} \mathrm{C}$ for $1 \mathrm{~min}$ and $68.0^{\circ} \mathrm{C}$ for $1 \mathrm{~min}$ with a final extension of $68.0^{\circ} \mathrm{C}$ for $5 \mathrm{~min}$. The reaction was put on hold at $4{ }^{\circ} \mathrm{C}$ until attended to.

Note: $\quad 60 / 54 / 53 / 52{ }^{\circ} \mathrm{C}$ corresponds to annealing temperatures of gyrA, gyrB, parC and parE genes, respectively. 
Table 1 Sequence of primers for detection of gyrA, gyrB, parC and parE genes

\begin{tabular}{|c|c|c|c|}
\hline Target gene & Nucleotide sequence $\left(5^{\prime}-3^{\prime}\right)$ & Product size (bp) & References \\
\hline \multirow[t]{2}{*}{ GyrA } & F 5' -ATGAGCGACCTTGCGAGAGAGAAATACACCG - 3' & 632 & [25] \\
\hline & R 5' - TTCCATCAGCCCTTCAATGCTGAGTCTTC - 3' & & \\
\hline \multirow[t]{2}{*}{ GyrB } & F 5' - AAGCGCGATGGCAAAGAAG - 3' & 1500 & [25] \\
\hline & R 5' - AACGGTCTGCTCATCAGAAAGG - 3' & & \\
\hline \multirow[t]{2}{*}{ ParC } & F 5'- CTATGCGATGTCAGAGCTGG - 3' & 270 & [26] \\
\hline & R 5'- TAACAGCAGCTCGGCGTATT - 3' & & \\
\hline \multirow[t]{2}{*}{ ParE } & F 5'- TCTCTTCCGATGAAGTGCTG - 3' & 240 & [26] \\
\hline & R 5'- ATACGGTATAGCGGCGGTAG - 3' & & \\
\hline
\end{tabular}

\section{PCR product purification}

The products of amplification of $\operatorname{gyr} A, \operatorname{gyr} B, \operatorname{par} C$ and parE genes were purified using DNA clean and concentrator $^{\mathrm{TM}}-25$ kit (Zymo research, Irvine, USA) according to manufacturer's instruction. This was to ensure that ultra-pure PCR products are recovered ahead of Sanger sequencing.

\section{DNA sequencing and analysis of mutation}

Sanger sequencing of the purified PCR products was achieved using the aforementioned primers of the topoisomerase genes on an ABI 3730XL DNA Analyzer. Analysis of the DNA sequences was performed by comparing with the reference $S$. Typhimurium strain LT2 genome (accession number AE006468.2) for $\operatorname{gyr} A$, gyrB, parC and parE genes (accession numbers AAL21173.1, AAL22694.1, AAL22048.1 and AAL22055.1, respectively) at GenBank database using the NCBI (National Centre for Biotechnology Information) BLAST (basic local alignment search tool) program. ExPASy (Expert Protein Analysis System) translate tool, SIB (Swiss Institute of Bioinformatics) was used to translate the nucleotide sequences into amino acid sequences. Global alignment tool EBI (European Bioinformatics Institute) was used to investigate for any mutations using Needleman-Wunsch algorithm (EMBOSS).

\section{Detection of plasmid-mediated quinolonone resistance genes (PMQR)}

Polymerase chain reaction (PCR) amplification of fluoroquinolones resistant genes: qnrA, qnrB and qnrS was performed on all Salmonella isolates using the primers [9] in Table 2. Genomic DNA extraction and PCR master-mix preparation were prepared as mentioned before.

PCR experiments were carried out according to the following cycling conditions for all three genes: initial denaturation - $94{ }^{\circ} \mathrm{C}$ for $30 \mathrm{~s}$; template denaturation $94{ }^{\circ} \mathrm{C}$ for 30 s; annealing $-55^{\circ} \mathrm{C}$ for 60 s; extension $-68^{\circ} \mathrm{C}$ for $60 \mathrm{~s}$; final extension $-68^{\circ} \mathrm{C}$ for $5 \mathrm{mins}$; and reaction was put on hold at $4{ }^{\circ} \mathrm{C}$ until amplicons were collected for agarose gel electrophoresis.

\section{Gel documentation}

The amplicons were resolved by agarose gel electrophoresis (1.5\% agarose) at $120 \mathrm{~V}$ for an hour and band visualisation done with the aid of UV-transilluminator (Vilber Lourmat, Collegien, France). The concentation of agarose used was more suitable for the expected band sizes in this work. The stained gel was captured unto a desktop computer using the infinity ${ }^{\oplus}$ software.

\section{Statistical analysis}

Data were entered into Microsoft excel and exported to STATA version 12 (Stata Corp, USA) for analysis. Descriptive statistics was used to summarize the distribution of various variables into tables and graphs. Differences between discrete variables were analysed using Fisher's exact test.

\section{Results}

Socio-demographic characteristics of the study population

Majority $(402 / 1036 ; 38.8 \%$ and $251 / 364 ; 69.0 \%)$ of the sampled population from the two study sites $(\mathrm{APH}$ and $\mathrm{KATH})$ were $\leq 5$ years old. The overall mean $( \pm \mathrm{SE})$ age (in years) of participants was $15.4 \pm 0.5$. The mean $( \pm \mathrm{SE})$ age (in years) of recruited patients seeking medical attention at $\mathrm{APH}$ and $\mathrm{KATH}$ was $18.7 \pm 0.6$ and $4.5 \pm 0.2$ respectively. At both sites, there were high proportion of males compared to females.

Table 2 Primers used for amplification of PMQR genes

\begin{tabular}{llcl}
\hline Name & Sequence & Size (bp) & References \\
\hline QnrA-FW & 5'-GGGTAT GGATATTATTGATAAAG-3' & 660 & {$[9]$} \\
QnrA-RV & 5'-CTAATCCG GCAGCACTATTA-3' & & \\
QnrB-FW & 5'-GGMATHGAAATTCGCCACTG-3' & 264 & {$[9]$} \\
QnrB-RV & 5'-TITGCYGYYCGCCAGTCGAA-3' & & \\
QnrS-FW & 5'-AGTGATCTCACCTTCACCGC-3' & 550 & {$[9]$} \\
QnrS-RV & 5'-CAGGCTGCAATTTTGATACC-3' & & \\
\hline
\end{tabular}




\section{Distribution of bacteremic pathogens}

Of 133 biobanked isolates cultured, 68 (51.1\%) and 16 (12\%) were identified as Salmonella Typhi and nontyphoidal Salmonella (NTS) respectively (Fig. 1). Other bacteriae identified included Escherichia coli (including ESBL; 11; 8.3\%), Staphylococcus aureus (including MRSA; 7; 5.3\%) and Klebsiella pneumoniae (5; 3.8\%). Salmonella Typhi was predominantly found in APH (56/ 68 ; 82.4\%) while NTS was high in KATH (9/16; 56.3\%).

\section{Salmonella from stool and oropharynx}

A total of 13 Salmonella strains were isolated from 418 stool specimens collected from both APH and KATH. Of the 13 strains, 4 (30.8\%) and 9 (69.2\%) were $S$. Typhi and NTS, respectively (Table 3). Salmonella was the only pathogen isolated from stool. Five hundred and fifty eight oropharyngeal specimens (OPS) were collected from the two study sites: APH - 401 (71.9\%) and KATH - 157 (28.1\%). Of the four (4) Salmonella strains isolated from 558 OPS, only $1(25.0 \%)$ was identified as $S$. Typhi and 3 (75.0\%) NTS (Table 3). All the Salmonella strains isolated from stool and OPS were from APH but not KATH.

\section{Serotyping of bacteremic isolates}

Serotyping of iNTS revealed that Salmonella Typhimurium $(10 / 16 ; 62.5 \%)$ was the most predominant serovar identified followed by Salmonella Enteritidis (5/16; $31.3 \%)$ and finally, $1(1 / 16 ; 6.2 \%)$ untypable isolate. Rate of isolation of Salmonella Typhimurium was significantly higher in APH than in KATH $(p=0.011$; Table 4), however, Salmonella Enteritidis was isolated from only KATH.
Table 3 Bacterial isolates from stool and oropharynx

\begin{tabular}{lll}
\hline Pathogen & $\mathrm{n}(\%)$ pathogens from & \\
\cline { 2 - 3 } & Stool & OPS \\
\hline S. Typhi & $4(30.8)$ & $1(25.0)$ \\
NTS & $9(69.2)$ & $3(75.0)$ \\
Total & $13(100)$ & $4(100)$ \\
\hline
\end{tabular}

\section{Antibiotic resistance profile}

Generally, first-line anti-Salmonella drugs (ampicillin, chloramphenicol, trimethoprim/sulfamethoxazole) recorded the highest rate of resistance in both $S$. Typhi and NTS isolates (between 33.8 and 50.0\%). Thirdgeneration cephalosporins (ceftazidime and ceftriaxone) and gentamicin had $100 \%$ efficacy rate in all serovars of Salmonella tested. Ciprofloxacin recorded significantly reduced susceptibility (intermediate) in both typhoidal and NTS (14.7 and 37.5\%, respectively).

\section{MIC determination for resistant and reduced-susceptible Salmonella strains to fluoroquinolones}

Of the 20 ciprofloxacin intermediate/resistant Salmonella isolates tested by MIC, only 5 (breakpoint concentration between 0.12 and $0.5 \mu \mathrm{g} / \mathrm{ml}$ ) were intermediate and no resistance recorded (Table 5).

\section{Identification of mutations within QRDR}

Thirteen isolates were selected (based on MIC values from 0.03 to $0.5 \mu \mathrm{g} / \mathrm{ml}$ ) for DNA product purification and subsequent sequencing prior to mutational analysis. Sequence analysis of gyrA gene revealed the presence of 5 different nonsynonymous mutations, with the most frequent mutation (Ile203Ser) occurring in 12 out of 13 isolates tested (Table 6). Gyrase B ( $g y r B)$ gene revealed 1

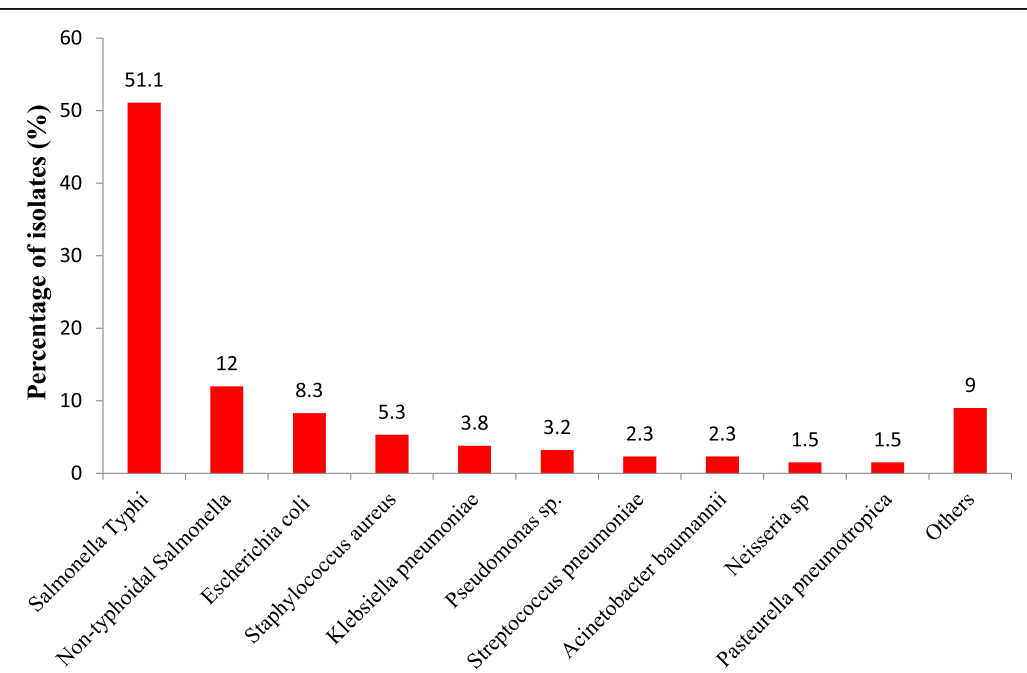

Fig. 1 Distribution of bacteremic isolates from study sites. Biobanked bacterial isolates were cultured and identified using standard microbiological culture methods and biochemical tests 
Table 4 Invasive NTS distribution among study population

\begin{tabular}{llll}
\hline Serovar & $\begin{array}{l}\text { KATH }[n(\%)] \\
(n=9)\end{array}$ & $\begin{array}{l}\text { APH [n(\%)] } \\
(n=7)\end{array}$ & $p$-value \\
\hline Salmonella Typhimurium & $3(18.8)$ & $7(43.8)$ & 0.011 \\
Salmonella Enteritidis & $5(31.1)$ & 0 & 0.034 \\
Untypable & $1(6.3)$ & 0 & - \\
\hline
\end{tabular}

nonsynonymous mutation in 3 out of 13 isolates, substituting amino acid phenylalanine with leucine at codon 601 (Phe601Leu). No mutation was observed in parC and parE genes. In gyrA mutation alone, Serovar Typhi recorded the highest mutation (5/13), followed by Typhimurium (4/13) and Enteritidis (4/13). All three isolates which harboured gyrB mutation were Salmonella Typhi. Again, 3 isolates, all $S$. Typhi possessed both gyrA and $\operatorname{gyr} B$ mutations. Only one $S$. Enteritidis isolate exhibited Lys154Asn gyrA mutation and $5 S$. Typhi isolates had a Glu133Gly mutation in gyrA gene (Table 6). The two isolates with the highest ciprofloxacin MIC $(0.5 \mu \mathrm{g} /$ $\mathrm{ml}$ ) had common amino acid substitutions resulting in 1 nonsynonymous mutation in gyrA gene (Ile203Ser).

\section{Detection of plasmid-mediated qnr genes}

Again, Of the 20 phenotypically resistant and/or intermediate Salmonella isolates to ciprofloxacin and nalidixic acid tested by singleplex PCR reactions, there was no amplification of $q n r A$ and $q n r B$ plasmid-mediated resistant genes. However, 2 isolates were found to harbour $q n r S$ resistant gene of molecular size $550 \mathrm{bp}$ (Fig. 2). Both isolates were non-typhoidal Salmonella strains from the blood ( $S$. Enteritidis) and oropharynx ( $S$. Typhimurium) of 11 and 1 year old children at KATH and $\mathrm{APH}$, respectively. Again, these two isolates recorded the highest MIC value of $0.5 \mu \mathrm{g} / \mathrm{ml}$ (Table 6).

\section{Discussion}

This study identified five different gyrA mutations and one $\operatorname{gyr} B$ nonsynonymous mutation in quinoloneresistant Salmonella enterica from human clinical isolates. Salmonella isolates harbouring plasmid-mediated fluoroquinolone resistant gene $q n r S$ was also identified in this study.

Table 5 MIC of fluoroquinolone resistant and reducedsusceptible Salmonella strains

\begin{tabular}{lll}
\hline Isolate number & MIC $(\mu \mathrm{g} / \mathrm{ml})$ & Interpretation \\
\hline 16,18 & 0.500 & I \\
$1,14,15$ & 0.120 & I \\
$2,5,6,8,13,17,19,20$ & 0.030 & $\mathrm{~S}$ \\
$3,4,7,9,10,11,12$ & 0.015 & $\mathrm{~S}$ \\
\hline
\end{tabular}

$I$ intermediate, $S$ sensitive
There was high frequency of gyrA gene mutation in this study than the other topoisomerase genes examined. This agrees with findings from Eaves et al., in that mutations occurring at the quinolone resistance determining regions of other topoisomerase genes are more uncommon than those observed in gyrA gene [27]. Thus, there might be other mechanisms of resistance playing an important role, as mutations in all but gyrA gene were rare. In Africa, the most common mutation known to account for ciprofloxacin non-susceptibility in most clinical Salmonella isolates is found in gyrA gene, followed by parC and $\operatorname{gyr} B$ genes, with no reported case of parE gene mutation [28]. As observed in this study, both $\operatorname{parC}$ and parE gene mutations were completely absent in the study populations, consistent with previous studies [29]. Report by Bae et al., showed a higher frequency (18 out of 27 isolates) of gyrA mutation (Asp87Gly) in nalidixic acid resistant $S$. Enteritidis from South Korea [30]. However, the present study identified only 2 nalidixic acid resistant S. Enteritidis with the same Asp87Gly gyrA mutation and had ciprofloxacin MIC $0.12 \mu \mathrm{g} / \mathrm{ml}$. Codons 83 and 87 of gyrA gene are widely known to be a common hotspot for gyrA mutation [31, 32], nevertheless, their frequency was much lower in the current study. Mutations at these codons, especially codon 87 , have been shown to be associated with decreased ciprofloxacin susceptibility and nalidixic acid resistance [31].

Other gyrA mutation was detected in $5 \mathrm{~S}$. Typhi isolates which resulted in amino acid substitution from glutamic acid to glycine at codon 133 with MIC of $0.03 \mu \mathrm{g} /$ $\mathrm{ml}$ ( 4 isolates) and $0.12 \mu \mathrm{g} / \mathrm{ml}$ (only one isolate). With these low MICs, it could be suggested that mutation of Glu133Gly alone could not necessarily lead to quinolone resistance in Salmonella. This agrees with findings from Eibach et al., who detected a Glu133Gly mutation in ciprofloxacin susceptible $S$. Typhi clinical isolate in Ghana with MIC of $0.06 \mu \mathrm{g} / \mathrm{ml}$ [29]. However, studies in Kenya found $11 S$. Typhi reduced ciprofloxacin susceptible isolates with the same gyrA mutation (Glu133Gly) [33].

Studies show that double mutations found in gyrase further reduce binding affinity of the enzyme-DNA complex to fluoroquinolones [34]. This agrees with the current study as $2 S$. Typhi isolates identified to have double mutations in $g y r A$ and $g y r B$ genes were MDR and also resistant to the quinolone nalidixic acid.

Gyrase B gene mutation was detected in only $3 S$. Typhi isolates which resulted in amino acid substitution from phenylalanine to leucine at codon 601 (Phe601leu). The first $\operatorname{gyr} B$ gene mutation (Glu466Asp) reported in Ghana was from $S$. Typhimurium [15], however, the present study identified gyrB mutation in $S$. Typhi, for the first time in Ghana. Findings from Tadesse et al., revealed a low proportion $(0.2 \%)$ of Salmonella gyrB mutation from human and animal sources in Africa [28]. 
Table 6 Summary of resistance profiles, target gene mutations and prevalence of PMQR genes

\begin{tabular}{|c|c|c|c|c|c|c|}
\hline \multirow[t]{2}{*}{ Serovar } & \multirow[t]{2}{*}{ Study site } & \multirow[t]{2}{*}{ Cip MIC $(\mu \mathrm{g} / \mathrm{ml})$} & \multirow[t]{2}{*}{ Coresistance } & \multicolumn{3}{|c|}{ Target mutations } \\
\hline & & & & gyrA & gyrB & $P M Q R$ \\
\hline \multirow[t]{3}{*}{ Typhi } & $\mathrm{APH}$ & 0.12 & AMPCSXTNATET & Ser83Tyr & Phe601Leu & \\
\hline & & & & Glu133Gly & & \\
\hline & & & & Ilez203Ser & & \\
\hline \multirow[t]{2}{*}{ Typhi } & $\mathrm{APH}$ & 0.03 & AMPCSXTTET & Glu133Gly & Phe601Leu & \\
\hline & & & & Ilez203Ser & & \\
\hline \multirow[t]{2}{*}{ Typhi } & $\mathrm{APH}$ & 0.03 & & Glu133Gly & & \\
\hline & & & & Ile203Ser & & \\
\hline \multirow[t]{2}{*}{ Typhi } & $\mathrm{APH}$ & 0.03 & & Glu133Gly & Phe601Leu & \\
\hline & & & & Ilez203Ser & & \\
\hline \multirow[t]{2}{*}{ Typhi } & $\mathrm{APH}$ & 0.03 & & Glu133Gly & & \\
\hline & & & & Ilez203Ser & & \\
\hline Enteritidis & KATH & 0.03 & AMPCSXTTET & Ile203Ser & & \\
\hline \multirow[t]{2}{*}{ Enteritidis } & KATH & 0.12 & & Asp87Gly & & \\
\hline & & & & Ile203Ser & & \\
\hline \multirow[t]{2}{*}{ Enteritidis } & KATH & 0.12 & & Asp87Gly & & \\
\hline & & & & Ilez203Ser & & \\
\hline Enteritidis & KATH & 0.50 & & Ilez203Ser & & anrs \\
\hline Typhimurium & $\mathrm{APH}$ & 0.03 & & Ilez203Ser & & \\
\hline Typhimurium & $\mathrm{APH}$ & 0.50 & AMPAMC & Ilez203Ser & & qnes \\
\hline Typhimurium & $\mathrm{APH}$ & 0.03 & AMPAMC & Lys154Asn & & \\
\hline Typhimurium & $\mathrm{APH}$ & 0.03 & AMPCSXTAMC & Ile203Ser & & \\
\hline
\end{tabular}

Molecular analysis by PCR detected the presence of quinolone resistance gene qurS in 2 non-typhoidal Salmonella isolates from the blood and oropharynx in patients attending health care at KATH and APH respectively. The 3 principal genes responsible for plasmid-mediated fluoroquinolone

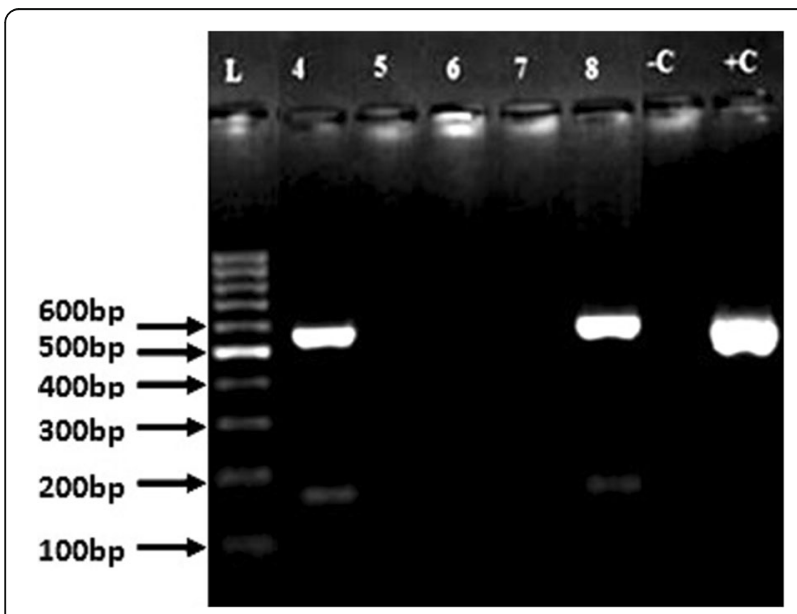

Fig. 2 Amplification and detection of qnrs plasmid-mediated fluoroquinolone resistant gene (molecular size $550 \mathrm{bp}$ ) by PCR. Lanes 4,8 are positive for anrs gene (550 bp). Lanes $-C,+C$ are negative and positive controls respectively.L = Molecular ladder of size $100 \mathrm{bp}$ resistance in Salmonella include qnrA, qurB and qurS genes [9]. Previous studies in Ghana showed the absence of all three genes [15, 29], indicating a more recent emergence of $q n r S$ resistant gene. Plasmids increase bacterial genetic diversity greatly through acquisition or loss of genes especially, those pertaining to resistance and/or virulence. Detection of $q n r S$ gene in this study might be due to indiscriminate use of over-the-counter antibiotics by humans, without complying to clinicians prescriptions. This could lead to increased selective pressure on the drugs and subsequently contributes to resistance. Again, there could be possibility of zoonotic transmission of these resistant genes [35, 36], as Dekker et al, has already reported on emergence of $q n r B$ resistant gene in poultry population in Ghana [37].

Variant qnrA1 of the qnrA gene family was the first plasmid-mediated fluoroquinolone resistant gene described, however, several studies show that this gene is not commonly found in Salmonella [9, 38, 39]. This might explain why none of the isolates tested in this study was positive for qnrA.

Dekker et al., detected Salmonella Poona plasmidmediated resistant gene qnrB2 in 3 out of 200 poultry meat samples collected from markets in Ghana [37]. In Africa, evidence-based findings of plasmid-encoded genetic determinants associated with fluoroquinolone resistance in 
Salmonella strains are generally rare [28]. Few cases of qnrB and $q n r S$ genes have been reported in South Africa [40] and Nigeria [8], respectively. Studies in Europe have reported on the increasing rate of $q n r B$ resistant genes in several European countries (including Spain, Italy and Netherlands) and these were mostly from animal sources (predominantly chicken and turkey) [41]. The most commonly reported $q n r B$ variant is qnrB2 and it is usually harboured in Salmonella serovars Agona, Derby, Enteritidis, Hadar, London and Montevideo [41]. Although qnrB resistant genes are often restricted to animal populations, there is a potential chance of future global transmission to humans, as variant $q n r B 19$ has already been implicated in human $S$. Typhimurium infection in Netherlands and Italy $[42,43]$. Studies in Scotland also revealed the presence of $q n r B$ and qnrS from returning travellers from Egypt and Nigeria [39]. Another study conducted in United States reported on low prevalence of plasmid-mediated fluoroquinolone resistant genes, particularly qurS [12, 44]. However, this study contrasts findings from some European (like Germany and Poland) and Asian countries, depicting regional differences in the prevalence of plasmid-mediated fluoroquinolone resistant genes [45].

To date, there are 9 variants of qnrS resistant gene (qnrS1 to qnrS9) identified, with qnrS1 being the most predominant [46]. Previous studies showed that qnrS1 alone was capable of conferring reduced susceptibility to ciprofloxacin even in the absence of $g y r A$ mutation [47]. Again, findings from Hopkins et al, in the United States demonstrated that quinolone resistant gene increased ciprofloxacin MIC to $0.38-0.78 \mu \mathrm{g} / \mathrm{ml}$ [13], giving credence to the fact that, $q n r$ genes might confer full resistance in the near future with MIC $\geq 1 \mu \mathrm{g} / \mathrm{ml}$ if strong surveillance system is not established to control spread of these plasmid-encoded genes.

Other plasmid mediated fluoroquinolone resistant genes not screened in this study include $q n r C$, q $n r D$, qnrVC, aac $\left(6^{\prime}\right)-\mathrm{lb}$ and plasmid-mediated enhanced efflux pump mechanisms by QepAB and OqxAB [48]. Studies show that the global prevalence of these genes are low [41]. Although $q n r$ genes are usually associated with plasmidencoded ESBL genes $[10,18]$, no ESBL gene was identified among the qnrS positive strains in this study.

Resistance of Salmonella to ciprofloxacin and other related fluoroquinolones has serious public health implications because this class of antimicrobials is commonly used to treat invasive forms of Salmonella infections. Mechanisms by these plasmid-mediated genetic determinants lead to low-level resistance that by itself does not exceed clinical breakpoint for susceptibility. However, it facilitates selection of higher level resistance and makes pathogens harbouring PMQR genes difficult to treat [48, 49]. The present study could not examine for the presence of other genetic determinants (such as $q n r C$, q $n r D$, qnrVC, $a a c\left(6^{\prime}\right)-I b-c r$, and $q e p A B$ genes) responsible for plasmidmediated fluoroquinolone resistance. Another limitation to this study was the inability to link the novel mutations (gyrA - Ile203Ser and Lys154Asn; and gyrB - Phe601Leu) to their involvement in reduced ciprofloxacin susceptibility/resistance within the QRDR. A suggested approach is to conduct a conjugational transfer experiment by introducing wild-type allele of the gyrA and gyrB genes into a broad host-range plasmid vector [15].

\section{Conclusion}

This study reports for the first time plasmid-mediated fluoroquinolone resistant gene qurS in Salmonella clinical isolates in Ghana. Nonsynonymous mutations (Asp87Gly, Glu133Gly and Ser83Tyr) which confer Salmonella reduced susceptibility to ciprofloxacin were also detected as reported in several studies [27, 29], with 3 other novel mutations likely to confer Salmonella resistance. We recommend surveillance systems to track the evolution of Salmonella plasmid-mediated resistant genes and to ensure proper use of antibiotics and control of severe infections.

\section{Abbreviations \\ APH: Agogo Presbyterian Hospital; BA: Blood Agar; CA: Chocolate Agar; CHRPE: Committee for Human Research Publication and Ethics; CLSI: Clinical and Laboratory Standards Institute; EBI: European Bioinformatics Institute; ESBL: Extended Spectrum Beta-lactamase; ExPASY: Expert Protein Analysis System; KATH: Komfo Anokye Teaching Hospital; KCCR: Kumasi Centre for Collaborative Research in Tropical Medicine; KNUST: Kwame Nkrumah University of Science and Technology; MIC: Minimum Inhibitory Concentration; MRSA: Methicillin-resistant Staphylococcus aureus; PCR: Polymerase Chain Reaction; PMQR: Plasmid-mediated Quinolone Resistance; QRDR: Quinolone Resistance Determining Region; SIB: Swiss Institute of Bioinformatics; TSI: Triple Sugar Iron Agar; WHO: World Health Organisation}

\section{Acknowledgements}

We are thankful to the DNA Analysis Core Laboratory (Institute of Plant and Microbial Biology, Academia Sinica, Taipei, Taiwan) for providing Sanger sequencing service.

\section{Authors' contributions}

All authors have read and approved the manuscript. EOD, MO, YAS, FM, SEP conceptualised and designed the experiments. MO, AS, GA, HK, SC, CK performed the experiments. MO, GA, IO, SEP collected and analyzed the data. GA, MO wrote the paper. AO, IO, NS, CK, EOD, MO, AS, YAS, SEP critically reviewed the manuscript.

\section{Funding}

The report was generated as part of a large study investigating severe typhoid burden in Ghana. Core funding for this study was received from the Bill and Melinda Gates Foundation. Additional funding for laboratory reagents was received from the KNUST research excellence fund (KREF) (VC/ ORG/15) and Academia Sinica (Taipei, Taiwan). The funding bodies played no role in design of the study and collection, analysis, and interpretation of data and in writing the manuscript.

\section{Availability of data and materials}

The datasets used and/or analysed during the current study are available from the corresponding author on reasonable request. 


\section{Ethics approval and consent to participate}

Permission was sought from all patients and their relatives before samples were taken. Written informed consent was obtained from all participants of the study by means of signature and/or thumbprinting. Children older than $7 \mathrm{yrs}$. but younger than $18 \mathrm{yrs}$. gave their assent together with parental/ guardian consent (written) before they were enrolled into the study. The main study protocol was reviewed and approved by the Committee for Human Research Publications and Ethics (CHRPE) at the School of Medical Sciences, Kwame Nkrumah University of Science and Technology (KNUST).

\section{Consent for publication}

Not applicable.

\section{Competing interests}

The authors (including Florian Marks, who is an editorial board member for BMC Infectious Diseases) declare that they have no competing interests.

\section{Author details}

'Kumasi Centre for Collaborative Research in Tropical Medicine, Kumasi, Ghana. ${ }^{2}$ Department of Medical Laboratory Technology, Kwame Nkrumah University of Science and Technology, Kumasi, Ghana. ${ }^{3}$ Department of Clinical Microbiology, Kwame Nkrumah University of Science and Technology, Kumasi, Ghana. ${ }^{4}$ Komfo Anokye Teaching Hospital, Kumasi, Ghana. ${ }^{5}$ Agogo Presbyterian Hospital, Agogo, Ghana. ${ }^{6}$ Department of Theoretical and Applied Biology, Kwame Nkrumah University of Science and Technology, Kumasi, Ghana. ${ }^{7}$ Institute of Plant and Microbial Biology, Academia Sinica, Taipei, Taiwan. ${ }^{8}$ Department of Epidemiology, International Vaccine Institute, Seoul, South Korea. ${ }^{9}$ Oxford University Clinical Research Unit, Wellcome Trust Major Overseas Programme, 764 Vo Van Kiet, Quant 5, Ho Chi Minh City, Vietnam. ${ }^{10}$ Department of Global and International Health, School of Public Health, Kwame Nkrumah University of Science and Technology, Kumasi, Ghana.

\section{Received: 2 July 2019 Accepted: 30 September 2019}

Published online: 28 October 2019

\section{References}

1. Mogasale V, Maskery B, Ochiai RL, Lee JS, Mogasale W, Ramani E, Kim YE, Park JK, Wierzba TF. Burden of typhoid fever in low-income and middleincome countries: a systematic, literature-based update with risk-factor adjustment. Lancet Glob Health. 2014;2(10):e570-80.

2. Tatavarthy A, Luna VA, Amuso PT. How multidrug resistance in typhoid fever affects treatment options. Ann N Y Acad Sci. 2014;1323:76-90.

3. Park SE, Pham DT, Boinett C, Wong VK, Pak GD, Panzner U, Espinoza LMC, von Kalckreuth V, Im J, Schütt-Gerowitt H. The phylogeography and incidence of multi-drug resistant typhoid fever in sub-Saharan Africa. Nat Commun. 2018;9(1):5094.

4. Wong VK, Baker S, Pickard DJ, Parkhill J, Page AJ, Feasey NA, Kingsley RA, Thomson NR, Keane JA, Weill F-X. Phylogeographical analysis of the dominant multidrug-resistant H58 clade of Salmonella Typhi identifies interand intracontinental transmission events. Nat Genet. 2015;47(6):632.

5. Su L-H, Chiu C-H, Chu C, Ou JT. Antimicrobial resistance in nontyphoid Salmonella serotypes: a global challenge. Clin Infect Dis. 2004;39(4):546-51.

6. Mills-Robertson F, Addy ME, Mensah P, Crupper SS. Molecular characterization of antibiotic resistance in clinical Salmonella typhi isolated in Ghana. FEMS Microbiol Lett. 2002;215(2):249-53.

7. Harish BN, Menezes GA, Sarangapani K, Parija SC. A case report and review of the literature: ciprofloxacin resistant Salmonella enterica serovar Typhi in India. J Infect Dev Ctries. 2008;2(04):324-7.

8. Cuypers WL, Jacobs J, Wong V, Klemm EJ, Deborggraeve S, Van Puyvelde S. Fluoroquinolone resistance in Salmonella: insights by whole-genome sequencing. Microb Genomics. 2018;4(7):1-9.

9. Cattoir V, Weill F-X, Poirel L, Fabre L, Soussy C-J, Nordmann P. Prevalence of qnr genes in Salmonella in France. J Antimicrob Chemother. 2007:59(4):751-4.

10. Robicsek A, Jacoby GA, Hooper DC. The worldwide emergence of plasmidmediated quinolone resistance. Lancet Infect Dis. 2006;6(10):629-40.

11. Aldred KJ, Kerns RJ, Osheroff N. Mechanism of quinolone action and resistance. Biochemistry. 2014;53(10):1565-74.

12. Sjölund-Karlsson M, Howie R, Rickert R, Krueger A, Tran T-T, Zhao S, Ball T, Haro J, Pecic G, Joyce K. Plasmid-mediated quinolone resistance among
non-typhiSalmonella enterica isolates, USA. Emerg Infect Dis. 2010;16(11): 1789.

13. Hopkins KL, Day M, Threlfall EJ. Plasmid-mediated quinolone resistance in Salmonella enterica, United Kingdom. Emerg Infect Dis. 2008;14(2):340.

14. Abgottspon $H$, Zurfluh $K$, Nüesch-Inderbinen $M$, Hächler $H$, Stephan R. Quinolone resistance mechanisms in Salmonella enterica serovars Hadar, Kentucky, Virchow, Schwarzengrund, and 4, 5, 12: i:-, isolated from humans in Switzerland, and identification of a novel qnrD variant, qnrD2, in S. Hadar. Antimicrob Agents Chemother. 2014;58(6):3560-3.

15. Al-Emran HM, Heisig A, Dekker D, Adu-Sarkodie Y, Cruz Espinoza LM, Panzner U, von Kalckreuth V, Marks F, Park SE, Sarpong N. Detection of a novel gyrB mutation associated with fluoroquinolone-nonsusceptible Salmonella enterica serovar Typhimurium isolated from a bloodstream infection in Ghana. Clin Infect Dis. 2016;62(suppl_1):S47-9.

16. Aldred KJ, McPherson SA, Wang P, Kerns RJ, Graves DE, Turnbough CL Jr, Osheroff N. Drug interactions with Bacillus anthracis topoisomerase IV: biochemical basis for quinolone action and resistance. Biochemistry. 2011; 51(1):370-81.

17. Barnard FM, Maxwell A. Interaction between DNA gyrase and quinolones: effects of alanine mutations at GyrA subunit residues Ser83and Asp87. Antimicrob Agents Chemother. 2001;45(7):1994-2000.

18. Nordmann P, Poirel L. Emergence of plasmid-mediated resistance to quinolones in Enterobacteriaceae. J Antimicrob Chemother. 2005;56(3):463-9.

19. Drlica K, Hiasa H, Kerns R, Malik M, Mustaev A, Zhao X. Quinolones: action and resistance updated. Curr Top Med Chem. 2009;9(11):981-98.

20. Kuijpers LM, Phe T, Veng CH, Lim K, leng S, Kham C, Fawal N, Fabre L, Le Hello S, Vlieghe E. The clinical and microbiological characteristics of enteric fever in Cambodia, 2008-2015. PLoS Negl Trop Dis. 2017;11(9):e0005964.

21. Thanh DP, Karkey A, Dongol S, Thi NH, Thompson CN, Rabaa MA, Arjyal A, Holt KE, Wong V, Thieu NTV. A novel ciprofloxacin-resistant subclade of H58 Salmonella Typhi is associated with fluoroquinolone treatment failure. Elife. 2016;5:e14003.

22. Hendriksen RS, Leekitcharoenphon P, Lukjancenko O, Lukwesa-Musyani C, Tambatamba B, Mwaba J, Kalonda A, Nakazwe R, Kwenda G, Jensen JD. Genomic signature of multidrug-resistant Salmonella enterica serovar Typhi isolates related to a massive outbreak in Zambia between 2010 and 2012. J Clin Microbiol. 2015;53(1):262-72.

23. Consortium IT, Wong VK, Holt KE, Okoro C, Baker S, Pickard DJ, Marks F, Page AJ, Olanipekun G, Munir H. Molecular surveillance identifies multiple transmissions of typhoid in West Africa. PLoS Negl Trop Dis. 2016;10(9): e0004781.

24. CLSI. Performance standards for antimicrobial susceptibility testing. CLSI supplement M100. 28th ed. Wayne: Clinical and Laboratory Standards Institute; 2018.

25. Mutai WC. Characterization of antibiotic resistance plasmids in Salmonella enterica serovar Typhi isolated in Nairobi, Kenya. Med Microbiol. 2016:1-139.

26. Chau T, Campbell Jl, Galindo CM, Van Minh HN, Diep TS, Nga TT, Van Vinh $C N$, Tuan $P Q$, Page AL, Ochiai RL, et al. Antimicrobial drug resistance of Salmonella enterica serovar typhi in asia and molecular mechanism of reduced susceptibility to the fluoroquinolones. Antimicrob Agents Chemother. 2007:51(12):4315-23.

27. Eaves DJ, Randall L, Gray DT, Buckley A, Woodward MJ, White AP, Piddock $L J$. Prevalence of mutations within the quinolone resistance-determining region of gyrA, gyrB, parC, and parE and association with antibiotic resistance in quinolone-resistant Salmonella enterica. Antimicrob Agents Chemother. 2004;48(10):4012-5.

28. Tadesse G, Tessema TS, Beyene G, Aseffa A. Molecular epidemiology of fluoroquinolone resistant Salmonella in Africa: a systematic review and meta-analysis. PLoS One. 2018;13(2):e0192575.

29. Eibach D, Al-Emran HM, Dekker DM, Krumkamp R, Adu-Sarkodie Y, Cruz Espinoza LM, Ehmen C, Boahen K, Heisig P, Im J. The emergence of reduced ciprofloxacin susceptibility in Salmonella enterica causing bloodstream infections in rural Ghana. Clin Infect Dis. 2016;62(suppl_1):S32-6.

30. Bae DH, Baek HJ, Jeong SJ, Lee YJ. Amino acid substitutions in gyrA and parC associated with quinolone resistance in nalidixic acid-resistant Salmonella isolates. Ir Vet J. 2013;66(1):23.

31. Lunguya $O$, Lejon V, Phoba M-F, Bertrand S, Vanhoof R, Glupczynski Y, Verhaegen J, Muyembe-Tamfum J-J, Jacobs J. Antimicrobial resistance in invasive non-typhoid Salmonella from the Democratic Republic of the Congo: emergence of decreased fluoroquinolone susceptibility and extended-spectrum beta lactamases. PLoS Negl Trop Dis. 2013;7(3):e2103. 
32. Ling J, Chan E, Lam A, Cheng A. Mutations in topoisomerase genes of fluoroquinolone-resistant salmonellae in Hong Kong. Antimicrob Agents Chemother. 2003;47(11):3567-73.

33. Al-Emran HM, Eibach D, Krumkamp R, Ali M, Baker S, Biggs HM, BjerregaardAndersen M, Breiman RF, Clemens JD, Crump JA. A multicountry molecular analysis of Salmonella enterica serovar Typhi with reduced susceptibility to ciprofloxacin in sub-Saharan Africa. Clin Infect Dis. 2016;62(suppl_1):S42-6.

34. Zayed AA-F, Essam TM, Hashem A-GM, El-Tayeb OM. 'Supermutators' found amongst highly levofloxacin-resistant E. coli isolates: a rapid protocol for the detection of mutation sites. Emerg Microb Infect. 2015;4(1):1-8.

35. Threlfall EJ. Antimicrobial drug resistance in Salmonella: problems and perspectives in food-and water-borne infections. FEMS Microbiol Rev. 2002; 26(2):141-8.

36. Andoh LA, Dalsgaard A, Obiri-Danso K, Newman M, Barco L, Olsen JE. Prevalence and antimicrobial resistance of Salmonella serovars isolated from poultry in Ghana. Epidemiol Infect. 2016;144(15):3288-99.

37. Dekker D, Eibach D, Boahen KG, Akenten CW, Pfeifer Y, Zautner AE, Mertens E, Krumkamp R, Jaeger A, Flieger A. Fluoroquinolone-resistant Salmonello enterica, Campylobacter spp., and Arcobacter butzleri from local and imported poultry meat in Kumasi, Ghana. Foodborne Pathog Dis. 2019;16(5): 352-8.

38. Gunell M, Webber MA, Kotilainen P, Lilly AJ, Caddick JM, Jalava J, Huovinen $P$, Siitonen A, Hakanen AJ, Piddock LJ. Mechanisms of resistance in nontyphoidal Salmonella enterica strains exhibiting a nonclassical quinolone resistance phenotype. Antimicrob Agents Chemother. 2009;53(9):3832-6.

39. Murray A, Mather $\mathrm{H}$, Coia J, Brown D. Plasmid-mediated quinolone resistance in nalidixic-acid-susceptible strains of Salmonella enterica isolated in Scotland. J Antimicrob Chemother. 2008;62(5):1153-5.

40. Govender N, Smith AM, Karstaedt AS, Keddy KH. Plasmid-mediated quinolone resistance in Salmonella from South Africa. J Med Microbiol. 2009;58(10):1393-4.

41. Veldman K, Cavaco LM, Mevius D, Battisti A, Franco A, Botteldoorn N, Bruneau M, Perrin-Guyomard A, Cerny T, De Frutos EC. International collaborative study on the occurrence of plasmid-mediated quinolone resistance in Salmonella enterica and Escherichia coli isolated from animals, humans, food and the environment in 13 European countries. J Antimicrob Chemother. 2011;66(6):1278-86.

42. García-Fernández A, Fortini D, Veldman K, Mevius D, Carattoli A. Characterization of plasmids harbouring qnrS1, qnrB2 and qnrB19 genes in Salmonella. J Antimicrob Chemother. 2008;63(2):274-81.

43. Dionisi AM, Graziani C, Lucarelli C, Filetici E, Villa L, Owczarek S, Caprioli A, Luzzi I. Molecular characterization of multidrug-resistant strains of Salmonella enterica serotype Typhimurium and monophasic variant (S. 4,[5], 12: i:-) isolated from human infections in Italy. Foodborne Pathog Dis. 2009; 6(6):711-7.

44. Frye JG, Jackson CR. Genetic mechanisms of antimicrobial resistance identified in Salmonella enterica, Escherichia coli, and Enteroccocus spp. isolated from US food animals. Front Microbiol. 2013:4:135.

45. Cavaco L, Korsgaard H, Sørensen G, Aarestrup FM. Plasmid-mediated quinolone resistance due to qnrB5 and qnrS1 genes in Salmonella enterica serovars Newport, Hadar and Saintpaul isolated from Turkey meat in Denmark. J Antimicrob Chemother. 2008;62(3):632-4.

46. Colomer-Lluch M, Jofre J, Muniesa M. Quinolone resistance genes (qnrA and qnrS) in bacteriophage particles from wastewater samples and the effect of inducing agents on packaged antibiotic resistance genes. J Antimicrob Chemother. 2014;69(5):1265-74

47. Hopkins KL, Wootton L, Day MR, Threlfall EJ. Plasmid-mediated quinolone resistance determinant qnrS1 found in Salmonella enterica strains isolated in the UK. J Antimicrob Chemother. 2007:59(6):1071-5.

48. Jacoby GA. Plasmid-mediated quinolone resistance. In: Antimicrobial Drug Resistance. Berlin: Springer; 2017. p. 265-8.

49. Martínez-Martínez L, Pascual A, Jacoby GA. Quinolone resistance from a transferable plasmid. Lancet. 1998;351(9105):797-9.

\section{Publisher's Note}

Springer Nature remains neutral with regard to jurisdictional claims in published maps and institutional affiliations.

\section{Ready to submit your research? Choose BMC and benefit from}

- fast, convenient online submission

- thorough peer review by experienced researchers in your field

- rapid publication on acceptance

- support for research data, including large and complex data types

- gold Open Access which fosters wider collaboration and increased citations

- maximum visibility for your research: over $100 \mathrm{M}$ website views per year

At BMC, research is always in progress.

Learn more biomedcentral.com/submissions 